\title{
UTILIZATION OF MANGO KERNELS FLOUR IN THE IMPROVEMENT OF BAKERY PRODUCTS
}

\author{
HAFEZ, M. Y., RAYA A. S. MOUSA. AND ASMA A. ELGINDY \\ Food Technology Research Institute, ARC, Giza, Egypt
}

(Manuscript received 29 March 2011)

\begin{abstract}
The present study was to utilize mango kernels wastes for improving some bakery products which could be analyzed for Physico-chemical, biological, bacteriological and rheological characteristics. Soaking in $1 \% \mathrm{NaCl}$ solution was carried out to get rid of toxic compounds such as amygdaline hydrocyanic acid and trypsin inhibitors. These treatments caused slight reduction of crude protein and total carbohydrates. This aforementioned treatment caused increasing in acid value and peroxide value as well as decreasing in unsaponification matter . Oil content and fatty acid composition weren't affected by this treatment. Bakery products supplemented with mango kernels flour contained the highest value of protein, oil, fiber and ash while it contained the lowest value of total carbohydrates. Supplementation of wheat flour by using mango kernels flour promoted rheological properties. The shelf life of the produced cake increased for 8 days at room temperature and for 28 days with cold storage. Statistical analysis results indicated no significant differences between the control sample and supplemented bakery products. Gain in the rat body weight in the final nutritional period increased by increasing the mango kernels flour addition.
\end{abstract}

\section{INTRODUCTION}

Mangoes (Mangifera Indica $L$ ) are considered among the most popular fruits grown in Egypt. The average total annual areas cultivated with mangoes are about 68356 feddans producing about 230873 tons of fruits. Mango kernels represent about $24 \%$ of the weight of the whole fruits. There are need to convert these refuse materials into available by products. Food researches interested in supplementing bakery products by mango kernels flour and many other dairy by - products rich in protein as a mean of lessening the malnutrition of animal protein and as a good source of protein. The current work is aiming to utilize mango kernels flour in the improvement of bakery products as well as enhance both nutritive value and microbiological quality to extend the shelf - life of the product. Mango kernels depend on the variety contains an average of $5.89 \%$ protein, $12.32 \%$ fat, $77.03 \%$ carbohydrates, $2.49 \%$ crude fibers and $2.27 \%$ ash (Atwa et. al., 2008). Mango kernel powder was used as an antioxidant agent for ghee. Its effect could be attributed to 
the phenolic compounds and also to the presence of phospholipids that helped to prolong the shelf life of stored ghee (Mona et. al., 2006). The total antioxidant capacity and phenolic content of edible portions and seeds of mango were studied by Soong and Barlow, (2004). Several studies had been carried out concerning the toxic compound removal from these kernels to be used as a food and feeding source, (Solis and Duran, 2004). The aim of the present work was to study the Physico - chemical, biological and rheological characteristics of mango kernel and its flour in the improvement of bakery products.

\section{MATERIALS AND METHODS}

Materials:

Representative samples of mangoes (Mangifera Indica L.), namely Balady, were obtained from juice extraction unit of the pilot plant of the Food Technology Research Institute, Agric. Res. Center, Giza, Egypt. These wastes were dried at $400^{\circ} \mathrm{C}$ in a drying oven, and then stored at room temperature $(25 \pm 2 \cdot c)$ for further uses.

Methods:

Preparation of mango kernels samples:

Mango stones were cleaned and washed twice with tap water, then left to dry in the air. After the stones were individually hammered to obtain the kernels of which the outer cover was removed by hand after soaking in $1 \%$ of $\mathrm{NaCl}$ solution for $12 \mathrm{hrs}$. at room temperature. Then dehydrated under vacuum for $2 \mathrm{hrs}$. to remove most of the water and the water residue was further eliminated by dehydration at $105{ }^{\circ} \mathrm{c}$ for 2 hrs..

Analytical Methods:

Moisture, total protein, ether extract, total ash, crude fiber and minerals were determined according to methods in the A.O.A.C., (2000). Total carbohydrates were calculated by difference.

Physico - chemical characteristics:

These include refractive index, acid and peroxide values, iodine value, saponification value, melting point, unsaponification matter which were determined according to the method described in the A.O.A.C. (2000).

Preparation of the fatty materials to methylation:

The methyl esters of mango kernel oil were prepared using benzene: methanol: concentrated sulfuric acid (10:86:4). Methylation was carried out at $70 \cdot \mathrm{c}$ for $24 \mathrm{hrs}$. according to the method described by Ludy et. al., (1968). Determination of the fatty acid methyl esters: 
Gas-liquid chromatography (Pye-unicam PRO-GC) was used for fractionation and determination of fatty acid methyl esters according to the method described by Zygadlo et. al., (1994).

Nutritional quality:

Amygdaline:

Determination of the amygdaline content (as hydrocyanic acid) in mango kernels (Amygdaline $=\mathrm{HCN} \times 16.9257$ ). Hydrocyanic acid was extracted from mango kernels samples according to the method reported by Cruess, (1958) while hydrocyanic acid content (raw and during the soaking stage) was determined according to the method described by the A.O.A.C., (2000).

Tannins:

Tannins were determined colorimetrically as described in A.O.A.C., (2000).

Phytic acid:

Phytic acid was determined according to the method of Wheeler and Ferrel, (1971).

Trypsin inhibitor:

Trypsin inhibitor was determined according to the method of Roy and Reo, (1971).

Utilization of mango flour in bakery products:

The mango flour was blended with the soft wheat flour in making sponge cake batter at levels of 15, 25 and $35 \%(w / w)$ of the wheat flour according to Nagao et. al., (1976) with some modifications The cake batter was baked in an automatic laboratory bakery oven at $180 \mathrm{C}$, then cooled and packaged in polyethylene.

Rheological properties:

Rheological characteristics of the resultant dough under investigation were determined according to the method described in A.A.C.C, (1990).

Sensory evaluation:

Sensory evaluation was carried out for formulations mango flour in $\mathrm{NaCl}$ solution $1 \%(T)$ and control. Taste, odor, color texture and the overall acceptability were evaluated according to Lanza et. al., (1995).

Statistical analysis:

Statistical analysis was applied to sensory and biological evaluation of adding different percentages from treated kernels flour. Data were treated to be for complete randomization design. Least significant difference (L.S.D.) was calculated at $1 \%$ level as significance. This analysis was carried out as mentioned by Snedecor and Cochran (1980).

Bacteriological evaluation: 
Total viable and fungi counts were enumerated as c.f.u./gm of the produced cakes at zero time and during the different intervals of both room temperature and cold storage according to the methods of (Leo, 1982) using the nutrient agar and malt extract agar media according to (Difco,1986).

Biological tests using rats:

Male albino rats average weight $80-89 \mathrm{~g}$. were obtained from the Research Institute of Ophthalmology, Giza, Egypt.

The biological assays were carried out to determine the gain in weight of rats for best meals. The effects of adding different percentage from treated mango kernels flour were biologically evaluated. The salt and vitamin mixture used in these experiments were as recommended by A.O. A.C, (2000). Test rats were kept out under normal healthy conditions and fed on basal diet for one week. The test animal includes 5 groups each of 6 rats for each diet (basal diet as control $(+)$ and control (-) protein free diet and fed for 8 weeks.

\section{RESULTS AND DISCUSSION}

Chemical composition of raw materials:

Data in Table (1) Show that the chemical composition of mango kernels were $5.93,12.39,2.51,2.37$ and 76.80 for crude protein, crude oil, crude fiber, total ash and Total carbohydrates respectively. Soaking in $1 \% \mathrm{NaCl}$ solution caused the decrement of crude protein and total carbohydrates, while slightly increment of crude oil . These results are in agreement with the findings of Radi (2005).

Table 1. Effect of soaking in $1 \% \mathrm{NaCl}$ solution on chemical composition of Mango kernel flours (on dry weight basis).

\begin{tabular}{|l|c|c|}
\hline \multirow{2}{*}{ Compounds \% } & Sample (control) & Treatment \\
\cline { 3 - 3 } & & $1 \% \mathrm{NaCl}$ solution \\
\hline Crude protein & 5.93 & 5.22 \\
\hline Crude oil & 12.39 & 12.97 \\
\hline Crude fiber & 2.51 & 2.81 \\
\hline Total ash & 2.37 & 2.45 \\
\hline Total carbohydrates & 76.80 & 76.55 \\
\hline
\end{tabular}


Table 2. Effect of soaking in $1 \% \mathrm{NaCl}$ solution on minerals of mango kernel flours (on dry weight basis).

\begin{tabular}{|l|c|c|}
\hline \multirow{2}{*}{$\begin{array}{c}\text { Mineral elements } \mathrm{mg} / \\
\text { 100gm }\end{array}$} & Sample (control) & Treatment \\
\cline { 3 - 3 } & & $1 \% \mathrm{NaCl}$ solution \\
\hline Macro-elements & & \\
\hline Calcium & 37.56 & 45.27 \\
\hline Phosphorus & 59.91 & 69.72 \\
\hline Magnesium & 169.37 & 188.49 \\
\hline Potassium & 649.52 & 880.33 \\
\hline Sodium & 289.98 & 327.37 \\
\hline Micro-elements & & \\
\hline Iron & 0.71 & 0.84 \\
\hline Zinc & 4.08 & 4.98 \\
\hline Copper & 0.44 & 0.59 \\
\hline
\end{tabular}

Table (2) Shows that mineral content of mango kernels proved to be a good source for some minerals such as $\mathrm{Ca}, \mathrm{P}, \mathrm{Mg}, \mathrm{K}, \mathrm{Na}, \mathrm{Fe}, \mathrm{Zn}$ and $\mathrm{Cu}$. Also, it was observed that raising of macro mineral content after treatment with $1 \% \mathrm{NaCl}$ solution especially, Potassium , Calcium , Phosphorus and Magnesium, as for the micro elements it could be noticed that soaking in $1 \% \mathrm{NaCl}$ solution caused an increment in Copper, Zinc and Iron.

Table 3. Effect of soaking in $1 \% \mathrm{NaCl}$ solution on physicochemical characteristics of mango kernels oil (on dry weight basis).

\begin{tabular}{|l|c|c|}
\hline \multirow{2}{*}{ Properties } & \multirow{2}{*}{ Sample (control) } & Treatment \\
\cline { 3 - 3 } & & $1 \% \mathrm{NaCl}$ solution \\
\hline Refractive index $40 \cdot \mathrm{C}$ & 1.4692 & 1.4684 \\
\hline Melting point & 34.22 & 34.56 \\
\hline Acid value & 0.11 & 0.14 \\
\hline Peroxide value & 0.74 & 0.82 \\
\hline Iodine value & 43.60 & 43.64 \\
\hline Saponification value & 189.65 & 189.59 \\
\hline Unsaponification matter \% & 1.52 & 1.21 \\
\hline
\end{tabular}

From table (3), it could be noticed that soaking in $1 \% \mathrm{NaCl}$ solution caused a reduction of refractive index, saponification value and unsaponification matter i.e. 
from 1.4642 to $1.4684,189.65$ to 189.5 and 1.52 to 1.21 respectively. On the other hand, it could be observed that the aforementioned treatment caused slight increasing in melting point, acid value, peroxide value and Iodine value (Zygadlo et al 1994)

From table (4), it could be noticed that soaking in alkaline solution $1 \% \mathrm{NaCl}$ caused an increment of total unsaturated fatty acids and decrement of saturated fatty acids. These results agree with Solis et. al., (2004).

Table 4. Effect of soaking in $1 \% \mathrm{NaCl}$ solution on fatty acid composition of mango kernels oil.

\begin{tabular}{|lc|c|c|}
\hline \multirow{2}{*}{ Fatty acids \% } & Sample (control) & Treatment \\
\cline { 3 - 4 } & & & $1 \%$ NaCl solution \\
\hline Lauric & $(12: 0)$ & 0.22 & 0.25 \\
\hline Myristic & $(14: 0)$ & 0.42 & 0.43 \\
\hline Palmitic & $(16: 0)$ & 11.74 & 11.39 \\
\hline Palmitoleic & $(16: 1)$ & $\mathrm{N} . \mathrm{D}$ & $\mathrm{N} . \mathrm{D}$ \\
\hline Stearic & $(18: 0)$ & 40.46 & 39.88 \\
\hline Oleic & $(18: 1)$ & 41.43 & 42.47 \\
\hline Linoleic & $(18: 2)$ & 5.57 & 5.43 \\
\hline Linolenic & 0.16 & 0.15 \\
\hline Total saturated & 52.84 & 51.95 \\
\hline Total unsaturated & & 47.16 & 48.05 \\
\hline
\end{tabular}

The changes in some antinutritional factors such as hydrocyanic acid, amygdaline, tannins, Phytic acid and trypsin inhibitor during treatment by soaking in $1 \% \mathrm{NaCl}$ solution for 12 hrs., at $25 \pm 2 \cdot \mathrm{C}$ are shown in table (5). The results indicate that soaking treatment caused marked reduction in the antinutritional factors of mango kernels flour. The reduction rate in hydrocyanic acid and amygdaline was $100 \%$ for treatments. On the other hand, tannins and Phytic acid removal was higher in $\mathrm{NaCl}$ solution $1 \%$ than in control. Finally Treatments of mango kernels flour are free from Trypsin inhibitor. These results agree with Radi (2005).

Table 5. Effect of soaking in $1 \% \mathrm{NaCl}$ solution on anti-nutritional factors of mango kernel flours (on dry weight basis).

\begin{tabular}{|l|c|c|}
\hline \multirow{2}{*}{ Compounds } & & Treatment \\
\cline { 3 - 3 } & Sample (control) & $1 \%$ NaCl solution \\
\hline Hydrocyanic acid (gm/100gm sample) & 0.05 & N.D \\
\hline Amygdaline (gm/100gm sample) & 0.73 & N.D \\
\hline Tannins (gm/100gm sample) & 56.46 & 35.34 \\
\hline Phytic acid $(\mathrm{gm} / 100 \mathrm{gm}$ sample) & 6.39 & 3.11 \\
\hline Trypsin inhibitor $(\mathrm{TIU} / \mathrm{mg})$ & N.D. & N.D. \\
\hline
\end{tabular}

$\mathrm{N} . \mathrm{D}=$ not detected 
Table 6. Effect of adding different levels of mango kernel flour on Chemical composition of prepared cake (on dry weight basis).

\begin{tabular}{|c|c|c|c|c|c|c|}
\hline \multirow{2}{*}{\multicolumn{2}{|c|}{ Type of cake }} & \multicolumn{5}{|c|}{ Component \% } \\
\hline & & \multirow{2}{*}{ Protein } & Fat & Fiber & Ash & $\begin{array}{l}\text { carbohydrat } \\
\text { e }\end{array}$ \\
\hline \multicolumn{2}{|c|}{ Control } & & 16.91 & 1.39 & 1.63 & 68.36 \\
\hline & $15 \%$ & 16.27 & 17.93 & 1.61 & 1.91 & 62.28 \\
\hline$(T)$ & $25 \%$ & 16.71 & 17.99 & 1.67 & 1.98 & 61.65 \\
\hline & $35 \%$ & 18.83 & 18.57 & 1.81 & 1.99 & 58.80 \\
\hline
\end{tabular}

Table (6) shows the chemical composition of cake and the effect of adding mango kernels flour on the chemical composition of cake. From these data, it could be noticed that, protein, fat, fiber and ash contents tended to increase by increasing the level of added mango kernels flour. On the contrary, total carbohydrates tended to decrease with increasing the supplementation level.The rheological properties are considered to be of great importance since they greatly influence the final acceptability of the food products. The obtaind data are in agreement with those reported by Radi (2005).and (Atwa et. al., 2008).

Table 7. Effect of adding different levels of mango kernel flour on Rheological properties of wheat flour

\begin{tabular}{|l|c|c|c|c|}
\hline \multicolumn{1}{|c|}{ Rheological data } & Control & $15 \%$ & $25 \%$ & $35 \%$ \\
\hline Water absorption (\%) & 55.2 & 60.3 & 62.2 & 63.5 \\
\hline Arrival time (min) & 1.5 & 2.5 & 3.0 & 3.5 \\
\hline Dough development (min) & 2.5 & 3.0 & 3.5 & 3.5 \\
\hline Dough stability (min) & 7.5 & 7.5 & 7.0 & 7.0 \\
\hline Degree of weakening (B.u) & 45.0 & 55.0 & 60.0 & 65.0 \\
\hline Dough energy (cm ${ }^{2}$ ) & 120.2 & 118.3 & 115.2 & 110.1 \\
\hline Dough extensibility (mm) & 210.0 & 210.0 & 205.0 & 200.0 \\
\hline Resistance to extension (B.u) & 410.0 & 480.0 & 540.0 & 560.0 \\
\hline Proportional number (R/ E) & 1095 & 2.29 & 2.63 & 2.80 \\
\hline
\end{tabular}

Control: Wheat flour (72\% extraction), Different levels of mango flours (15, 25\&35\%)

Table (7) indicates that dough stability, dough energy and dough extensibility decreased with increasing the percentage of mango kernels flour in the formula while water absorption, arrival time, dough development, degree of weakling, resistance to extension and proportional number were increased with increasing the percentage of mango kernels flour (Atwa et. al., 2008). 
Table 8. Effect of adding different levels of mango kernel flour on Sensory evaluation of prepared cake

\begin{tabular}{|c|c|c|c|c|c|c|}
\hline \multicolumn{2}{|c|}{ Type of cake } & Color & Texture & Taste & Odor & Overall acceptability \\
\hline \multicolumn{2}{|c|}{ Control } & $8.02^{\mathrm{ab}}$ & $7.53^{\mathrm{b}}$ & $7.99^{\mathrm{b}}$ & $8.02^{\mathrm{ab}}$ & $8.18^{\mathrm{ab}}$ \\
\hline & $15 \%$ & $8.54^{\mathrm{a}}$ & $8.32^{\mathrm{ab}}$ & $8.46^{\mathrm{ab}}$ & $8.20^{\mathrm{ab}}$ & $8.44^{\mathrm{ab}}$ \\
\hline$T$ & $25 \%$ & $8.69^{\mathrm{a}}$ & $8.50^{\mathrm{a}}$ & $8.69^{\mathrm{a}}$ & $8.36^{\mathrm{ab}}$ & $8.74^{\mathrm{a}}$ \\
\hline & $35 \%$ & $7.33^{\mathrm{bc}}$ & $7.32^{\mathrm{bc}}$ & $7.17^{\mathrm{bc}}$ & $7.15^{\mathrm{bc}}$ & $7.30^{\mathrm{bc}}$ \\
\hline \multicolumn{2}{|c|}{ L.S.D } & 0.36 & 0.31 & 0.42 & 0.35 & 0.39 \\
\hline
\end{tabular}

The sensory evaluation was carried out to define the best formula being acceptable among other ones. The measured sensory characteristics included color, texture, taste, odor and overall acceptability. The results and statistical analysis in table (8) indicate no significant difference between the control sample and the formulated meals containing mango kernels flour, especially for color and overall acceptability (Radi 2005).

Table 9. Effect of adding different levels of mango kernel flour on Microbial evaluation

\begin{tabular}{|c|c|c|c|c|c|c|c|c|c|c|}
\hline $\begin{array}{c}\text { Storage } \\
\text { Period }\end{array}$ & Zero & Time & 2 & days & 4 & days & 6 & Days & 8 & days \\
\hline $\begin{array}{c}\text { Type of } \\
\text { cake }\end{array}$ & T.C. & M.Y. & T.C. & M.Y. & T.C. & M.Y. & T.C. & M.Y. & T.C. & M.Y. \\
\hline Control & 50 & 25 & 70 & 40 & 90 & 60 & 120 & 90 & 160 & 100 \\
\hline $15 \%$ & 40 & 20 & 60 & 35 & 80 & 40 & 110 & 70 & 120 & 85 \\
\hline $25 \%$ & 35 & 15 & 40 & 30 & 70 & 30 & 100 & 60 & 100 & 75 \\
\hline $35 \%$ & 30 & 13 & 35 & 20 & 35 & 25 & 90 & 45 & 80 & 55 \\
\hline
\end{tabular}

T.C $=$ Total count

M.Y. = Mold and yeast

Table (9) shows the microbial evaluation of the final product during storage at the ambient temperature for 8 days. There was a trend decrease in the total viable count from the control up to the treatment $35 \%$ replacement at zero time storage, on the other hand, there was negligible numbers of molds and yeasts at zero time storage.

from the same table, it could be noticed that the neumerating of total count and mold and yast decresed by incresing the mango kernels flour addition than the control sample. 
We suggest that this slow growth of the microbial count related to the contained polyphenols which have the fungistatic properties being play an important role in inhibition of molds and yeasts growth (Nwokolo \& Smartt 1996).

Overly we suggest that the prolongation of shelf - life at room temp. may be due to above mentioned factor in addition to the little amount of air contained in the headspace of the polyethylene sacks and the permeability of the polyethylene containers and the decrease in moisture content of the product

Table 10. Effect of adding different levels of mango kernel flour on Microbial evaluation as C.F.U. /gm of prepared cake during cold storage

\begin{tabular}{|c|l|l|l|l|l|l|l|l|l|l|}
\hline $\begin{array}{c}\text { Storage } \\
\text { Period }\end{array}$ & Zero & time & 7 & days & 14 & days & 21 & Days & 28 & days \\
\hline $\begin{array}{c}\text { Type of } \\
\text { cake }\end{array}$ & T.C. & M.Y. & T.C. & M.Y. & T.C. & M.Y. & T.C. & M.Y. & T.C. & M.Y. \\
\hline Control & 50 & 25 & 60 & 30 & 80 & 40 & 100 & 50 & 110 & 65 \\
\hline $15 \%$ & 40 & 20 & 50 & 25 & 70 & 30 & 80 & 40 & 100 & 50 \\
\hline $25 \%$ & 35 & 15 & 40 & 20 & 55 & 25 & 65 & 35 & 80 & 40 \\
\hline $35 \%$ & 30 & 13 & 35 & 15 & 45 & 20 & 60 & 25 & 75 & 30 \\
\hline
\end{tabular}

T.C $=$ Total count

M.Y. = Mold and yeast

By the same manner, Table (10) illustrated the microbial evaluation of the supplemented cake with mango flour during cold storage for 28 days.

The previous mentioned table demonstrated that the total viable count as c.f.u./ gm of the final product after cooling, the obtained data explained the effect of storage conditions on the microbial behavior along the storage periods. The microbial growth of all countered numbers, (Total Count, Molds and Yeasts) were slower than the samples stored at room temperature. Although, there were negligible numbers of molds and yeasts at the beginning of storage. The maximum growth of microorganisms reached to 110 and 65 microbe /gm of the product after 28 days at cold storage with control while the lowest growth of microorganism with 35\% mango kernel flour, this due to antioxidant agent. (Nwokolo and Smartt 1996).

The average change in body weight of rats is summarized in table (11). It could be observed that adding different percentages of mango kernels to the untreated flour was more effective for the growth of rats Compared to the treated (control). The increase of growth occurred with the increase in the percentage of added mango kernels flour. 
Table 11. Food intake, body weigh and feed efficiency ratio for rats feeding on mango flours for 35 days

\begin{tabular}{|c|c|c|c|c|c|c|c|}
\hline \multirow[t]{2}{*}{ Diets* } & \multirow{2}{*}{$\begin{array}{c}\text { Initial } \\
\text { body } \\
\text { weight } \\
\text { ( } g / r a t)\end{array}$} & \multirow{2}{*}{$\begin{array}{c}\text { final body } \\
\text { weight } \\
\text { ( g/rat) }\end{array}$} & \multicolumn{2}{|c|}{$\begin{array}{c}\text { Body weight } \\
\text { gain }\end{array}$} & \multirow{2}{*}{$\begin{array}{l}\text { Daily gain } \\
\text { in body } \\
\text { weight } \\
\text { ( g/rat) }\end{array}$} & \multirow{2}{*}{$\begin{array}{c}\text { Daily } \\
\text { food } \\
\text { intake for } \\
\text { rat } \\
\text { ( } g / r a t)\end{array}$} & \multirow{2}{*}{$\begin{array}{c}\text { Feed } \\
\text { efficiency } \\
\text { ratio }\end{array}$} \\
\hline & & & $\mathrm{g} / \mathrm{rat}$ & $\%$ & & & \\
\hline Basal $\operatorname{diet}(+)$ & 85 & 115 & 30 & 35.3 & 0.86 & 7.39 & 0.116 \\
\hline Control(-) & 83 & 106 & 23 & 27.7 & 0.66 & 5.81 & 0.114 \\
\hline $15 \%$ & 86 & 117 & 31 & 36.1 & 0.89 & 7.83 & 0.114 \\
\hline (T) $25 \%$ & 89 & 121 & 32 & 36.0 & 0.91 & 7.87 & 0.116 \\
\hline $35 \%$ & 88 & 120 & 32 & 36.4 & 0.91 & 7.87 & 0.116 \\
\hline
\end{tabular}

*=Basal diet: casein, Control: proteins free Diet, $\mathrm{T}$ : mango flour by soaking in $\mathrm{NaCl}$ solution $1 \%$

The data in table (11): show the evaluation of diet containing different percentage of control and treated mango kernels flour compared to those fed on added casein.

In general, mango kernels is a good source of high quality protein important in human and animal nutrition, and by blending with other plant proteins, will produce well balanced diets. Thus experiments must be carried out to study the acceptability of incorporation of mango kernels in some conventional of food items (Difco 1986).

\section{REFERENCES}

1. A. A. C. C. 1990. Approved method of American Association of Cereal Chemists. Published by American Association of Cereal chemists, Ins. St. Poul. Minnesota, U.S.A.

2. A. O. A. C. 2000. International Official Method of Analysis, 17th ed. Association Official Agricultural Chemists, Maryland, U.S.A.

3. Atwa, M. A., O. M. M. Radi and K. H. M. El -Waseif. 2008. Physico- chemical, biological rheological and functional properties of processed mango kernels and its flour. Egypt. J. of Appl.Sci., 23(4B) 2008

4. Cruess, W. V. 1958. In: Commercial fruit and vegetable products. (4th edn), Mc Graw-Hill, Book company New York, P.738.

5. Difco. 1986. Difco Manual of Dehydrated Culture Media and Reagents for Microbiology Clinical Laboratory. Detroit, Michigan

6. Lanza, C. M., E. Pagiarini and F. Tamselli. 1995. Sensory and chemical evaluation of frozen blood orange juice. Agric. Mediterranean., 125:421-426.

7. Leo, R. Diliello. 1982. Methods in Food and Dairy Microbiology. -A laboratory 
Training Manual for Quality Control Tests. Avi publishing Company , INC.Westport , Connecticut.

8. Ludy, J. E. Barford, R. A. Bard, S. Fand and D. Magidman. 1968. A Rapid and Quantitative Procedure for the Preparation of Methyl Esters of Butter, Oil and other Fats . J. Am .Oil Chem. Soc. 45: 549-552.

9. Mona, M. A., Enayat M. H. and Amina H. H. 2006. Effect of mango (Mangifera Indica L.) seed kernels as antimicrobial and antioxidant agent. $1^{\text {st }}$ international Conference \& Exhibition on Food \& Tourism. 1-3 March, 2006, Cairo, Egypt.

10. Nagao, S., S. Imai., T. Sato and H. Otsubo. 1976. Quality characteristics of soft wheats and their use in Japan .I. Methods of assessing wheat suitability for Japanese products . Cereal Chem.53:988-997

11. Nwokolo, E. and J. Smartt. 1996. Food and Feed from Legumes and Oilseeds published by Chapman \& Hall 2-6 Boundary Row, London SE18 HN.

12. Radi, O. M. M. 2005. Studies on the utilization of Some Fruit Kernels in the Improvement of Bakery Products. The First Scientific Conference for University Educational Development in Egypt (13 - 14 / 4 / 2005) Port Said.

13. Roy, O. N. and P. S. Reo. 1971. Evidence, isolation, purification and some properties of trypsin inhibitor in lathyrus sativus. J Agric. Food Chem., 19, 257.

14. Snedecor, W. G. and W. G. Cochran. 1980. Statistical methods $17^{\text {th }}$ ED Iowa State Univ. press Ames., Iowa, USA.

15. Solis, F. J. and B. M. Duran. 2004. Mango seed uses thermal behavior of mango seed fat and its mixture with cocoa butter. Bioresource Technology, 92 issue 1, 7178.

16. Soong, Y. Y. and P. J. Barlow. 2004. Antioxidant activity and phenolic content of selected fruit seeds. Food Chem., 88:411-417.

17. Wheeler, E. I. and R. E. Ferrel. 1971. A method for Phytic acid determination in wheat and wheat fractions. Cereal Chem., 48:312.

18. Zygadlo, J. A., R. E. Morero, R. E. Abburra and C. A. Guzman. 1994. Fatty acid composition in seed oils of some Onagraceae. J. Am. Oil Chem. Soc., 71: 915-916. 
الإستفادة من دقيق بذور المانجو في تحسين منتجات المخابز

محمد يوسف حافظ ، ريه على السيد ، أسمه أحمد الجندى

$$
\text { معه بحوث تكنولوجيا الأغنية - مركز البحوث الزراعية - جيزة - مصر }
$$

تهدف هذة الدراسـة إلى الاستفاده من مخلفات المـانجو فى تحسين بعض منتجات المخابز حيث تم تقدير الخواص الطبيعية والكيمائية والريولوجية والبكتريلوجية والبيولوجية لبذور المانجو والتى نهي عوملت للتخلص من المواد السـامه (الامجدالين وحمض الهيدروسيانيك ومثبطسات انزيم التربسين)

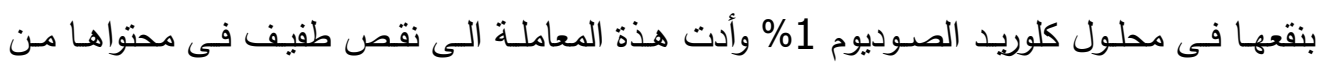
البروتين والكربوهيدرات كذلك تأثرت الخواص الطبيعية لزيت بذور المانجو مثل حدوث زيادة في رقم

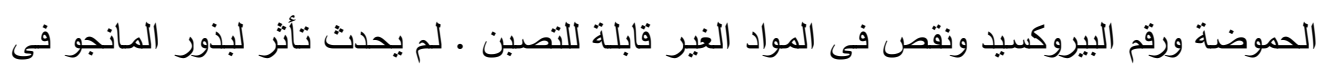

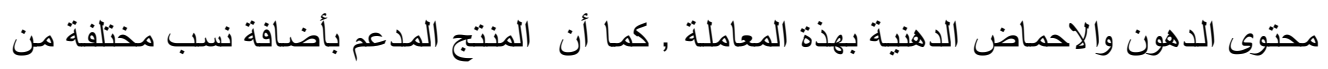
دقيق بذور المانجو المعامل أدى الى حدوث زيادة فى محتواها من البروتين والدهون والالياف والرماد

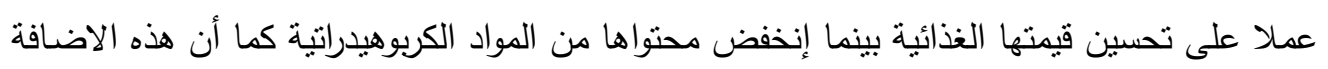

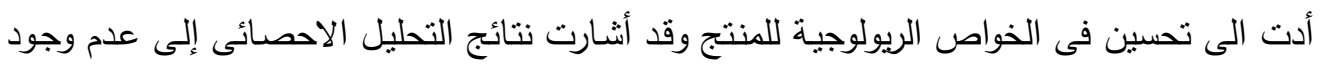

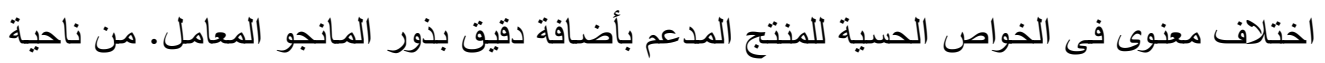

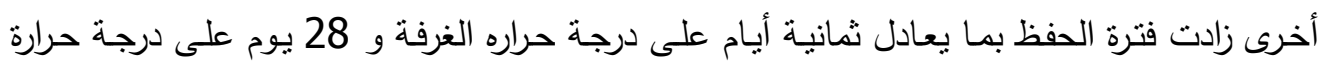

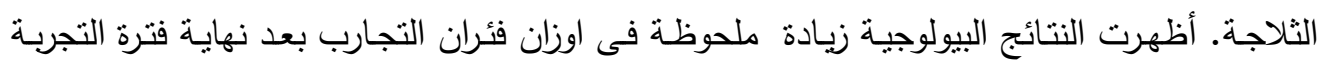
وبخاصة بزيادة نسبة الإضافة. 